\title{
Kontrowersje wokół wizerunku lekarza w reklamie — podejście normatywne
}

\section{Controversy over the image of a doctor in advertising - a normative approach}

\author{
dr hab. Marzena Barańska \\ Uniwersytet Jagielloński, Wydział Zarządzania i Komunikacji Społecznej, Instytut Kultury \\ ORCID: 0000-0003-0026-9803 \\ e-mail: marzena.baranska@uj.edu.pl
}

\begin{abstract}
Prawo do informacji jest jednym z podstawowych praw przysługujących jednostce. Zakres przekazywanych treści może dotyczyć wyrobów farmaceutycznych i ma istotne znaczenie w realizacji prawa do ochrony zdrowia. Producenci wyrobów farmaceutycznych, korzystając z perswazyjności przekazu reklamowego, dokonują wyboru odpowiednich metod i technik oddziaływania, które wpływają na wyroby dokonywane przez konsumentów. Celem artykułu jest omówienie stosowanych praktyk w zakresie ukazywania wizerunku lekarza w przekazach reklamowych, jako narzędzia perswazyjnego oddziaływania w obliczu obowiązującego ustawodawstwa w Polsce. Z uwagi na obowiązujące ograniczenia prawne dotyczące udziału lekarzy w reklamach za interesujące uznano zagadnienie wykorzystania wizerunkiem lekarza w przekazach reklamowych w obliczu obowiązujących reglamentacji normatywnych i pozanormatywnych. Na potrzeby niniejszego opracowania przyjęto tezę: ukazywany w reklamach wyrobów farmaceutycznych wizerunek lekarza może wprowadzać klientów w błąd i, mimo krytycznej oceny opinii publicznej, nie wpływa na zmianę aktualnie obowiązującego ustawodawstwa, dając asumpt reklamodawcom do projekcji obrazów, w których osoby obdarzane z racji rzekomo wykonywanego zawodu zaufaniem społecznym polecają leki, co nie pozostaje bez wpływu na decyzje zakupowe konsumentów. Za podstawowe uznano pytanie badawcze, w jakim stopniu normatywne zakazy dotyczące udziału lekarzy w reklamach są stosowane praktyce. Z uwagi na powyższe zastosowano następujące metody badawcze: obserwacji, egzegezy tekstów prawnych, komparatystycznej, analizy zawartości treści.
\end{abstract}

Keywords

marketing, reklama, wyroby farmaceutyczne, lekarz, wizerunek

The right to information is one of the fundamental rights of the individual. The scope of the content transferred may concern pharmaceutical products, which is important in the implementation of the right to health. Manufacturers of pharmaceutical products use the persuasiveness of the advertising message to influence their decisions on consumers. Current practices indicate that the appropriate selection of tools and techniques of influence is essential for successful marketing. Promotional slogans emphasizing the value and effectiveness of a product combined with the dynamics of the message and image stimulate interest of potential buyers. Particular role is attributed to the presence of a doctor, a dentist, a laboratory, their participation often determines the credibility of economic statements.

Slowa kluczowe
marketing, advertising, pharmaceuticalproducts, doctor, image

JEL: M370

Str. $41-52$ 


\section{Bibliografia}

Albin, K. (2002). Reklama: przekaz, odbiór, interpretacja. Warszawa-Wrocław: Wyd. Naukowe PWN.

Aronson, E. (1995). Człowiek - istota społeczna. Warszawa: Wyd. Naukowe PWN

Barta, J. i Markiewicz, R. (2002). Wokół prawa do wizerunku. Zeszyty Naukowe Uniwersytetu Jagiellońskiego. Prace z Prawa Wtasności Intelektualnej, 80, 11-31.

Błeszyński, J. (2005). Glosa do wyroku SN z dnia 27 lutego 2003 r., IV CKN 1819/00. Orzecznictwo Sądów Powszechnych, (6), poz. 75.

Burgiel, A. (2005). Znaczenie naśladownictwa i wpływów społecznych w zachowaniach konsumentów. Katowice: Wyd. UE.

Cialdini, R. (2008). Wywieranie wplywu na ludzi. Teoria i praktyka. Gdańsk: GWP.

Cyran, M. (2010). Natura prawna maski artystycznej. Palestra, (11-12), 123-137.

Decyzja GIF-P-R-481-15/RS/04 z dnia 9 kwietnia 2004 r.

Decyzja GIF-P-R-481-36/RB/05 z dnia 23 sierpnia 2005 r.

Decyzja GIF-P-R-481-54/RB/05 z dnia 30 grudnia 2005 r

Decyzja GIF-P-R-450/9-4/ZW/11 z dnia 6 maja 2011 r.

Decyzja GIF-P-R-450/72-5/JD/11 z dnia 22 maja 2012 r.

Decyzja GIF-P-R-450/22-2/JD/12 z dnia 23 maja 2012 r.

Decyzja GIF-P-R-450-25-/6/JD/15 z dnia 24 sierpnia 2015 r.

Dyrektywa Rady 84/450/EWG z dnia 10 września 1984 r. dotycząca reklamy wprowadzającej w błąd, DzU L 250 z 19.09.1984 r.

Fennis, B. M. i Stroebe, W. (2010). The Psychology of Advertising. Hove: Psychology Press.

Gackowski, T. i Łączyński, M. (red.). (2008). Analiza wizerunku w mediach. Podręcznik. Warszawa: Wyd. Instytutu Dziennikarstwa UW.

Grzegorczyk, A. (2012). Funkcje bohatera w reklamie telewizyjnej. W: A. Kozłowska (red.), Strategia komunikacji reklamowej z konsumentem (s. 141-170). Warszawa: Wyższa Szkoła Promocji.

Grzelińska, A. (2016). Lekarz z Wrocławia ukarany za telewizyjna reklamę. Pozyskano z http://www.gazetawroclawska.pl/ zdrowie/a/lekarz-z-wroclawia-ukarany-za-telewizyjna-reklame,9779661

Grzybowski, S. (1957). Naruszenie prawa do wizerunku przez rozpowszechnienie podobizny. Warszawa.

Hogan, K. (2001). Psychologia perswazji: strategie i techniki wywierania wpływu na ludzi. Warszawa: Jacek Santorski.

Jachnis, A. (1998). Reklama jako komunikacja perswazyjna. W: A. Jachnis i J. F. Terelak (red.), Psychologia konsumenta i reklamy. Bydgoszcz: Oficyna Wydawnicza Branta.

Keller, K. L. (2011). Strategiczne zarządzanie marka. Warszawa: Wolters Kluwer.

Konstytucja Rzeczypospolitej Polskiej z dnia 2 kwietnia 1997 r., DzU z 1997 r. Nr 78 poz. 483.

Kotler P. (1997), Marketing Management. Analysis, Planning Implementation and Control. Englewood Cliffs: Prentice-Hall.

Kozłowska, A. (2013). Bohater reklamowy, czyli jak budować wiarygodność w reklamie. Kwartalnik Collegium Ekonomiczno-Społecznego Studia i Prace, (1), 119-137.

Kraus, A. i Zoll, F. (1929). Polska ustawa o zwalczaniu nieuczciwej konkurencji. Komentarz. Poznań.

Kurosz, K. (2015). Artystyczne wykonanie jako przedmiot ochrony - uwagi na tle najnowszego orzecznictwa sadowego, ZNUJ 2015/4/26-46.

Pieńkos, J. (1996). Stownik łacińsko-polski. Łacina w nauce i kulturze. Warszawa: Wyd. Prawnicze.

Pluta, E. (2001). Public relations - moda czy konieczność? Teoria i praktyka. Warszawa: Twigger.

Powszechna Deklaracja Praw Człowieka i Obywatela z dnia 10 grudnia 1948 r., DzU z 1977 r. Nr 38 poz. 167.

Ricoeur, P. (1989). Język, tekst, interpretacja. Warszawa: PIW.

Ritterman, S. (1937). Komentarz do ustawy o prawie autorskim. Kraków: Leon Frommer.

Rozporządzenie Parlamentu Europejskiego i Rady (WE) nr 593/2008 z dnia 17 czerwca 2008 r. dotyczące prawa właściwego dla zobowiązań umownych. Dz. Urz. L 177/6 z 4.07.2008.

Rozporządzenie nr 864/2007 z dnia 11 lipca 2007 r. dotyczącego zobowiązań pozaumownych. Dz. Urz. L 199/40 z 31.07.2007.

Rudnicki, S. (1992). Ochrona dóbr osobistych na podstawie art. 23 i 24 kc w orzecznictwie Sądu Najwyższego w latach 1985-1991. Przegląd Sądowy, (1).

Sagan, M. (1996). Reklama żywności w świetle polskiego prawa. Przegląd Prawa Handlowego, (5), 16-23.

Sampson, E. (1996). Jak tworzyć własny wizerunek. Warszawa: Dom Wydawniczy ABC.

Stownik języka polskiego PWN (1995). Warszawa: PWN.

Steafniuk, K. (1970). Naruszenie prawa do wizerunku przez rozpowszechnienie podobizny. Państwo i Prawo, (1).

Szpunar, A. (2006). Zadośćuczynienie za szkodę niemajątkowa, Kraków: Oficyna Wydawnicza Branta.

Świerczyński, M. (2007). Produkty lecznicze i wyroby farmaceutyczne. W: E. Traple (red.), Prawo reklamy i promocji. Warszawa: LexisNexis. 
Turkiewicz, J. (2013). Budowanie wizerunku w ochronie zdrowia na przykładzie lekarzy w Polsce (Building the reputation in the health industry. The case of physician in Poland). Journal of Health Sciences, 3(11), 133-142.

Uchwała składu 7 sędziów SN z 16 lipca 1993 r., I PZP 28/93. LexisNexis nr 300642, OSNCP 1994, nr 1, poz. 2.

Ustawa z dnia 18 maja 1964 r. Kodeks cywilny., DzU 1964 nr 16 poz. 93.

Ustawa z dnia 29 grudnia 1992 r. o radiofonii i telewizji. Tekst jednolity, DzU 2017.1414.

Ustawa z dnia 4 lutego 1994 r. o prawie autorskim i prawach pokrewnych. Tekst jednolity, DzU 2017 nr 0, poz. 880.

Ustawa z dnia 5 grudnia 1996 r. o zawodach lekarza i lekarza dentysty, Tekst jednolity, DzU 2017 nr 0, poz. 125.

Wiktor, J. W. (2001). Promocja. System komunikacji przedsiębiorstwa z rynkiem. Warszawa: Wyd. Naukowe PWN.

Winiarska-Lisowska, M. (2011). Ochrona prawa do wizerunku. Pozyskazno z http://www.kopipol.pl/wp-content/ uploads/2011/11/Ochrona_prawa_wizerunku.Pdf

Wojnicka, E. (1990). Prawo do wizerunku w ustawodawstwie polskim. Zeszyty Naukowe Uniwersytetu Jagiellońskiego. Prace z Prawa Własności Intelektualnej, (56).

Wyrok Sądu Apelacyjnego w Warszawie z dnia 2 kwietnia 2015 r., I ACa 1295/14, Podmiot prawa do wizerunku. LEX nr 1768739.

Wyrok Sądu Apelacyjnego w Warszawie z dnia 22 maja 2015 r., I ACa 1741/14, LEX nr 1755241.

Wyroku Sądu Najwyższego z dnia 20 maja 2004 r., II CK 330/03, LEX nr 686639.

Wyrok Sądu Najwyższego z dnia 2 października 2007 r., II CSK 289/07, Orzecznictwo Sądu Najwyższego Izba Cywilna 2008/12/140.

Wyrok Sądu Najwyższego z dnia 7 października 2009 r., III CSK 39/09, OSNC 2010, nr D, poz. 100.

Wyrok Sądu Ochrony Konkurencji i Konsumentów z dnia 22 lipca 2009 r., XVII Ama 26/09, Dz. Urz. UOKiK. 2009/4/32.

Żabiński, L. i Śliwińska, K. (2002). Marketing: koncepcje, badania, zarządzanie. Warszawa: PWE. 